\title{
経年化した廃棄物埋立処分地からの浸出水の 脱窒処理に関する基礎的検討 \\ A PRELIMINARY EXPERIMENT ON DENITRIFICATION OF WASTE LANDFILL LEACHATE
}

\author{
和田有朗 1 ・ 中道民広 $2 \cdot$ 八木正博 $3 \cdot$ 松本敏秀 $4 \cdot$ 釘宮晃一 5 道奥康治 6 \\ Nariaki WADA, Tamihiro NAKAMICHI, Masahiro YAGI, Toshihide MATSUMOTO, \\ Akikazu KUGIMIYA and Kohji MICHIOKU \\ 1正会員 神戸大学大学院 工学研究科（†657-8501 神戸市灘区六甲台町1-1） \\ 2非会員 神戸市環境局（广650-8570 神戸市中央区加納町6-5-1） \\ 3非会員 神戸市環境保健研究所（干650-0046 神戸市中央区港島中町4-6） \\ 4正会員 (株タクマ（†660-0806 兵庫県尼崎市金楽寺町2-2-33） \\ 5正会員 株大林組（†108-8502 東京都港区港南2-15-2 品川インターシティB棟） \\ 6フェロー会員 神戸大学大学院教授 工学研究科（†657-8501 神戸市灘区六甲台町1-1）
}

\begin{abstract}
A laboratory experiment on denitrification was carried out in order to reduce nitrogen load from municipal landfill leachate. Nitrogen was efficiently removed by feeding sludge of the leachate pond into the tanks, which could activate denitrification bacteria. Although inorganic reducing agent such as iron powder was not able to make the whole water mass anoxic, denitrification took place by supplying organic matters such as methanol, hydrogen feeding agent, etc.. It is considered that small amount of anoxic water film produced on surfaces of container and carriers might contribute to denitrification, although the bulk water is kept aerobic. It is found that organic matters contained in the leachate is so insufficient that nitrification liquid circulation does not work well for denitrification.
\end{abstract}

Key Words : landfill leachate, municipal solid waste, denitrification, inorganic deoxidization

\section{1. はじめに}

内陸に埋め立てられた廃棄物堆積層では, 降水浸透・ 地下水流出がアンモニア態窒素・金属諸成分の負荷をも たらし，河川水域・沿岸域におよぼす環境影響が䀣念さ れる．埋め立て直後の期間においては高濃度の物質負荷 が継続するため, 本格的な施設による廃水処理が必要か つ有効である。しかし，時間を経て堆積層が安定化し物 質濃度が減少すると, 突発的な負荷上昇が見られる出水 期を除けばやや低水準の負荷が長期間にわたり継続する ため，低廉・簡便な廃水処理と持続的で緩やかな水質管 理が望ましい.

研究対象は標高 $350 \mathrm{~m}$ の山地内に設置された敷地面積 $65 \mathrm{ha}$ の一般廃棄物処分場である。浸出水は貯水容量 $20,000 \mathrm{~m}^{3}$ の貯留池にいったん貯められ，約 $500 \mathrm{~m}^{3} /$ dayの処 理速度で硝化一脱窒処理されている. しかし，埋立終了 後からすでに 25 年以上を経過して, 稼働中の廃水処理施
設も老朽化しているため, 施設を速やかに閉鎖して経済 的で省力的な浄化方式に切り替えることが望まれている. 浸出水貯留池ではアンモニア性窒素やマンガンなどの濃 度が高く嫌気的である．特に窒素負荷を軽減するには硝 化・脱窒が必要であり，著者らは貯留池において，これ までマイクロバブル・エアレータによる硝化技術の実験

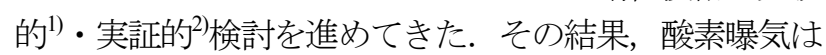
アンモニア性窒素から硝酸への酸化を促進するとともに マンガンなど金属類の不溶化・沈殿を促進することを確 認した，その一方で，浸出水の嫌気性を利用した硝化水 の脱窒促進がもう一つの課題である. 本研究では, マイ クロバブルによって硝化された浸出水の効率的な窒素除 去を実現するために文，脱窒工程を基礎的・実験的に検 討することを目的とする.

生活排水など一般下水を対象とする窒素除去技術とし ては, 生物学的な硝化液循環法・自己固定化法・生物膜 法などがあり，化学的処理法としてはイオン交換法・電 気透析法などが知られている ${ }^{4)}$. 硝酸性窒素で污染され 


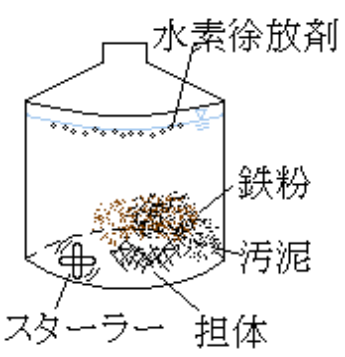

図-1 実験容器

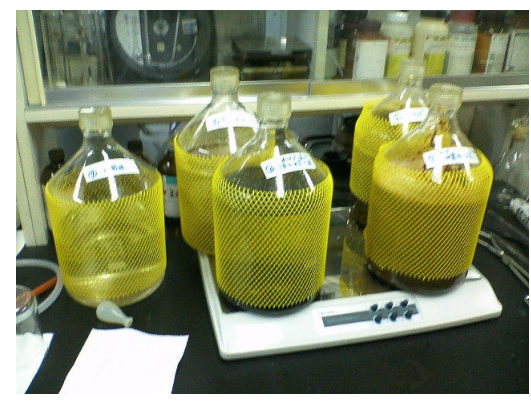

写真-1 実験の様子

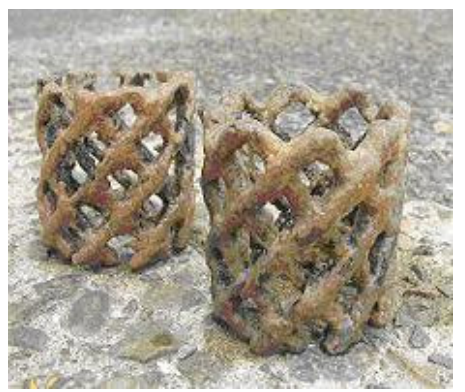

写真-2＼cjkstart実験に使用した担体
表-1 実験条件（実験 I：2006 年 7 月 11 日 8 月 18 日） (実験 II: 2006 年 8 月 18 日 9 月 11 日)

\begin{tabular}{|c|c|c|c|c|c|}
\hline Case & 実験 & 試験体 & 還元剤 & 有機物 & 脱窒菌 \\
\hline \multirow{2}{*}{ (1) } & I & 硝化水 5L & 鉄粉 $10 \mathrm{~g}$ & - & - \\
\hline & II & 硝化水 $5 \mathrm{~L}$ & 鉄粉 $10 \mathrm{~g}$ & 水素徐放剤 $10 \mathrm{~g}$ & 底泥 $1 \mathrm{~g}$ \\
\hline \multirow[b]{2}{*}{ (2) } & I & 硝化水 5L & 鉄粉 $10 \mathrm{~g}$ & メタノール $0.5 \mathrm{~g}$ & - \\
\hline & II & $\begin{array}{c}\text { 実験 I の水 } 2.5 \mathrm{~L} * \\
\quad+\text { 硝化水 } 2.5 \mathrm{~L}\end{array}$ & 鉄粉 $10 \mathrm{~g} *$ & メタノール $0.5 \mathrm{~g}$ & 担体 \\
\hline \multirow[b]{2}{*}{ (3) } & I & 硝化水 5L & 鉄粉 $10 \mathrm{~g}$ & 水素徐放剤 $10 \mathrm{~g}$ & - \\
\hline & II & 硝化水 5L & 鉄粉 $10 \mathrm{~g}$ & 水素徐放剤 $10 \mathrm{~g}$ & $\begin{array}{c}\text { 底泥 } 1 \mathrm{~g} \\
\text { 担体 }\end{array}$ \\
\hline \multirow[b]{2}{*}{ (4) } & I & 硝化水 5L & 鉄粉 $10 \mathrm{~g}$ & 水素徐放剂 $10 \mathrm{~g}$ & 底泥 $100 \mathrm{~g}$ \\
\hline & II & $\begin{array}{c}\text { 実験 I の水 } 2.5 \mathrm{~L}^{*} \\
\quad+\text { 硝化水 } 2.5 \mathrm{~L}\end{array}$ & 鉄粉 $10 \mathrm{~g} *$ & 水素徐放剤 $10 \mathrm{~g} *$ & 底泥 100g* \\
\hline \multirow[b]{2}{*}{ (5) } & I & $\begin{array}{l}\text { 硝化水 } 2.5 \mathrm{~L} \\
+ \text { 原水 } 2.5 \mathrm{~L} \\
\end{array}$ & 鉄粉 $10 \mathrm{~g}$ & (原水) & 底泥 $100 \mathrm{~g}$ \\
\hline & II & $\begin{array}{c}\text { 実駚 I の水 } 2.5 \mathrm{~L}^{*} \\
\quad+\text { 硝化水 } 1 \mathrm{~L} \\
\quad+\text { 原水 } 1.5 \mathrm{~L}\end{array}$ & 鉄粉 $10 \mathrm{~g}^{*}$ & (原水) & 底泥 $100 \mathrm{~g} *$ \\
\hline \multirow{2}{*}{ (6) } & $\mathrm{I}$ & 硝化水 5L & - & 水素徐放剂 $10 \mathrm{~g}$ & - \\
\hline & II & 硝化水 5L & 鉄粉 $10 \mathrm{~g}$ & 水素徐放剂 $100 \mathrm{~g}$ & 底泥 $1 \mathrm{~g}$ \\
\hline \multirow{2}{*}{ (7) } & $\mathrm{I}$ & 硝化水 5L & - & - & - \\
\hline & II & 硝化水 $5 \mathrm{~L}^{*}$ & - & - & - \\
\hline
\end{tabular}

※(1)〜6で゙は, スターラーで低速摚抖する. (5)の（原水）とは, 貯留池から 廃水処理施設に入る直前の浸出水を有機物供給源として添加することを意味 する. (2)，(4)，(5)，(7)に付した*は，実験 Iの試料水を引き継いで使用した ことを意味寸る. 担体は微生物の付着基質として脱窒菌の脱空効果を活性化 させる機能を有する．廃水処理施設の脱窒塔で使用されている担体（ポリエ チレン製（大日本プラスチック㑣)，ネットリングNL5252E）を本実験での 担体として転用する (写真-2)。担体の密度は 4,700 個 $/ \mathrm{m}^{3}, 210 \mathrm{~cm}^{3} /$ 個, 比表 面積 $94 \mathrm{~m}^{2} / \mathrm{m}^{3}, 201 \mathrm{~cm}^{2}$ /個である. 担体によって污泥の付き方に差があったた め, ブラシて擦って均質にし，2 3cm に切断し実験容器に投入した

た地下水を対象とする水処理としては，副島ら5)や李らの による脱窒技術の研究がある. 生活排水は濃度があまり 変わらないのに対し，本研究で対象とする浸出水は，埋 め立て物や埋め立ての進渉状況により変動する．特に経 年化した場合には，有機物と窒素とリンのバランスが崩 れることが一般下水との大きな相違点であり，これらを 含めた脱窒技術に関する知見が十分に得られていないの が現状である。

\section{2. 実験方法 ${ }^{3)}$}

図-1のように5Lの密閉可能な容器に試料水と各種物質 を投入し，表-1のように第1回目の実験（実験I）を実施 した．脱窒反応における投入物質の役割を表-2に要約す る. 試料水は，廃水処理施設内の第2散水ろ床塔出口か
表-2 各種投入物質に期待される機能

\begin{tabular}{|c|c||c|c|c|c|c|c|}
\hline 投入物 & 効果 & 鉄粉 & $\begin{array}{c}\text { 水素 } \\
\text { 徐放剤 }\end{array}$ & $\begin{array}{c}\text { メタール } \\
\text { ノー }\end{array}$ & 原水 & 底泥 & 担体 \\
\hline \hline 還元剤 & $\begin{array}{l}\text { 酸素を奪い, 還元環 } \\
\text { 境を作る. }\end{array}$ & $\bigcirc$ & $\triangle$ & $\triangle$ & - & - & - \\
\hline 有機物 & $\begin{array}{l}\text { 水素供与体として, } \\
\text { 有機物を与をる. }\end{array}$ & - & $\bigcirc$ & $\bigcirc$ & $\bigcirc$ & $\bigcirc$ & - \\
\hline 脱窒菌 & $\begin{array}{l}\text { 硝酸態窒素を窒素ガ } \\
\text { スに還元する. }\end{array}$ & - & - & - & - & $\bigcirc$ & $\bigcirc$ \\
\hline
\end{tabular}

※水素徐放剂とメタノールに関しては，水素供与体として有機物供給の機 能を期待しているが，水素供与体として消費されない分は酸化分解されて 酸素を消費して還元的環境をもたらす効果もあることから，還元剤として の機能として をを付記している．ここで，水素徐放剤とは水素を徐々に放 出するように工夫したもので，長期間にわたって水素の効果が持続するた めに使用するものである．実験で使用したアムテクリーンNは脱窒促進阂 でPanasonic.TR-AMNO101の製品である. 平均炭素数17.1の高級脂肪酸組 成物を用い，その組成はあらかじめ脱窒性能が評価されているステアリン 酸65重量\%，パルミチン酸30重量\%，ミリスチン酸5重量\%組成物である7). これは反応速度が遅く，脱窒素量が少なく，人手をかけないで機能すると いう目的で用いられたものである.

ら採水した。この地点において浸出水に含まれるアンモ

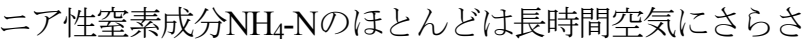

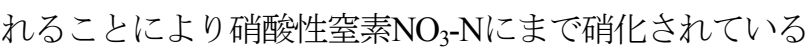
ので，マイクロバブル曝気を実施している貯留池内で起 こっている硝化を想定したものである．以後，これを 「硝化水」と記す．還元凨としては，寺尾の実験8) と同様 に鉄粉を使用した，有機物源としては，水素徐放剤（ア ムテクリーン N)，メタノール，原水（貯留池から廃水 処理施設に入る直前の水 : 硝化液循環を想定) の三種類 を用いた．前二者については還元機能も併せて期待して いる．水素徐放剤（表-2参照）は，高級脂肪酸を長期間 にわたり徐々に供給するという利点帛がある。メタノー ルに関しては，硝酸性窒素1gの脱窒に対して約2倍必要 とされており ${ }^{10)}$ ，本実験も同様に約2倍とした。ここで， 硝酸性窒素濃度が $50 \mathrm{mg} / \mathrm{L} て ゙ ，$ 水量が $5 \mathrm{~L}$ であるため，窒 素の負荷は $0.25 \mathrm{~g} （ 50 \mathrm{mg} / \mathrm{L} \times 5 \mathrm{~L}=250 \mathrm{mg})$ となる．従って, メタノール量は2倍となるよう $0.5 \mathrm{~g}$ を投入した。また， 原水の有機物濃度はBOD : 10〜280mg/L，COD $\mathrm{CO}_{\mathrm{Mn}}: 12$ $35 \mathrm{mg} / \mathrm{L}, \quad \mathrm{SS}: 3 \sim 38 \mathrm{mg} / \mathrm{L}, \quad \mathrm{T}-\mathrm{N}: 38 \sim 85 \mathrm{mg} / \mathrm{L}, \quad \mathrm{NH}_{4}-\mathrm{N}$ : 32〜 80mg/Lである. なお，原水の水質に幅があるが， これは降水量の多寡等によって浸出水の濃度が大きく変 動するためである，次に，貯留池の底から底泥を採取し て, 脱窒菌供給源として使用した。 底泥投入の有無から 底泥の脱窒促進効果を確認することが目的である（表1）. (7)は還元剂，有機物，脱窒菌のいずれも無添加の 参照ケース（コントロール）である．写真-1に実験の様 
子を示す。一連の実験は，恒温槽を用いずに自然温度 $\left(20^{\circ} \mathrm{C}\right)$ 条件の下で実施された. 脱窒の進行速度によっ ては，硝酸イオンが枯渴して反応が停止する試料があっ た，そのため，2006年8月18日より硝化水を適宜添加し て，表-1のような実験条件のもとで実験I継続した.

(1)(3)(6)では各投入物質の脱窒反応におよぼす効果を明 らかにすること，(2)(4)(5)では脱窒速度におよぼす各因子 の影響を確認するために設定されている. 実験IIの(2)と (3)では，担体を実用すると水中の窒素濃度の低下にどの ような効果があるのかを検証した. (4)と(5)では，硝酸イ オンの消費が大きかったため，同年8月29日に試料水の 半分を原水に置換してさらに実験を継続した. 実験開始 直後の数日間においては毎日採水して反応状況を計測し た. その後, 反応が緩やかになると採水回数を週2回程 度に減らした. 10項目の水質成分濃度を計測したが，本 文では脱窒反応に対して重要な7項目に限定して報告す る. 表-3に各種項目の測定・分析方法を示す.

\section{3. 実験結果と考察}

（1）窒素成分の経時変化（実験 I, II, 図-2 5）

実験Iにおける窒素成分の経時変化を図-2 5(左側)に 示す．まず，有機物を添加しない(1)のケースにおいても 最終的にはT-Nが若干減少している（図-2左側）。後述 のようにTOCが緩やかに減少している (図-9左側) こと を考慮すると, 硝化水にもともと含まれている多少の有 機物が水素供与体として機能し, わずかに脱窒が進行し たと考えられる. これに対してメタノールを添加した(2) の場合には, (1)よりもかなり大きな速度で脱窒が進行し
表-3 測定 · 分析方法

\begin{tabular}{|c|c|c|}
\hline 測定・分析項目 & 測定・分析器具 & 測定・分析方法 \\
\hline 全窒素（T-N） & \multirow{2}{*}{ 分光光度計 } & 紫外線吸光光度法 \\
\hline アンモニア性窒素（ $\left(\mathrm{NH}_{4}-\mathrm{N} ）\right.$ & & インドフェノール青吸光光度法 \\
\hline 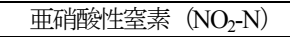 & \multirow{2}{*}{$\begin{array}{c}\text { イオンクロマト } \\
\text { グラフ }\end{array}$} & \multirow{2}{*}{ イオンクロマトグラフ法 } \\
\hline 硝酸性窒素（ $\mathrm{NO}_{3}-\mathrm{N} ）$ & & \\
\hline 溶存酸素濃度（DO） & \multirow{2}{*}{ 多項目水質計 } & \multirow{2}{*}{ 電極法 } \\
\hline 酸化還元電位（ORP） & & \\
\hline 全有機炭素（TOC） & TOC 計 & 燃焼酸化-赤外線式 TOC 分析法 \\
\hline
\end{tabular}

ている.

脱窒菌供給源として底泥を添加した(4)のケース（有機 物供給源は水素徐放剤) では, 脱窒がかなり促進されて いる．底泥とともに有機物供給源として原水を添加した (5のケースについても, (4)と同程度の脱窒反応が進行し

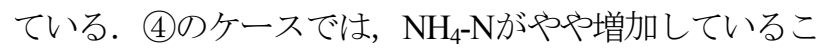

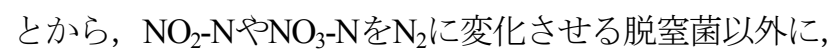
底泥が自己分解したときに発生するアンモニアの存在も 考えられる. (5)ケースは, 前述のように硝化液循環法 に相当する考え方で原水 (貯留池から廃水処理施設に入 る直前の水）を添加したものである. もともと浸出水に $\mathrm{NH}_{4}-\mathrm{N}$ が多く含まれるため実験開始時における $\mathrm{NH}_{4}-\mathrm{N}$ 濃 度は他のケースよりも高い，しかし，ORPは正で酸化的 環境に維持されていたため (図-8左側), $\mathrm{NH}_{4} \rightarrow \mathrm{NO}_{2} \rightarrow$ $\mathrm{NO}_{3}$ へと硝化が進んでいる（図-6）。これに対して, (4) のケースではORPが負であったため（図-8左側）， $\mathrm{NH}_{4}$ の一部は酸化されることなく残留している.

還元剂（鉄粉）を添加しない(6)と参照ケース（全ての 物質が無添加）の(7)を比較すると，いずれの水質項目も ほぼ同様の挙動を示しており，今回の実験条件では(6)の 水素徐放剤の添加だけでは脱窒がほとんど進行しないこ とがわかる. (3)と(6)を比較すると，鉄粉が還元剤として 脱窒におよぼす効果が顕著である。還元剤は容器全体の

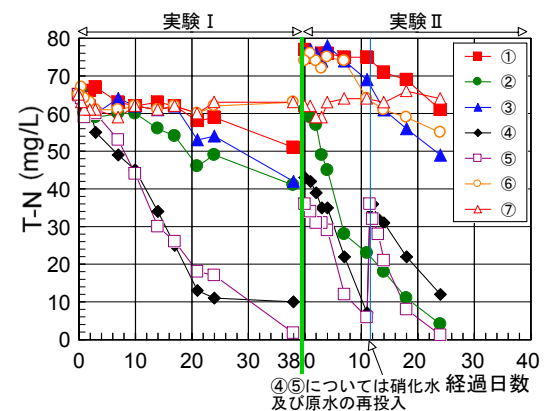

図-2 全窒素T-N (実験I, II)

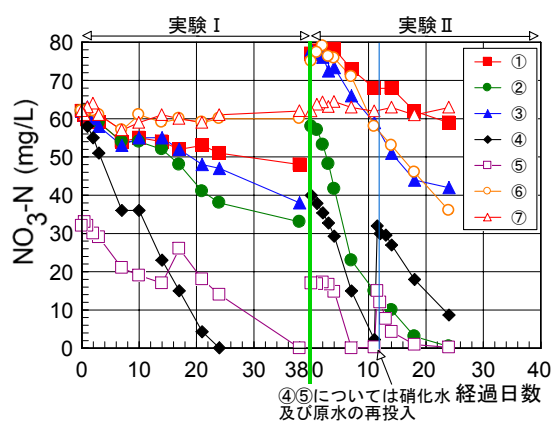

図-5 硝酸性窒素 $\mathrm{NO}_{3}-\mathrm{N}$ (実験I, II)

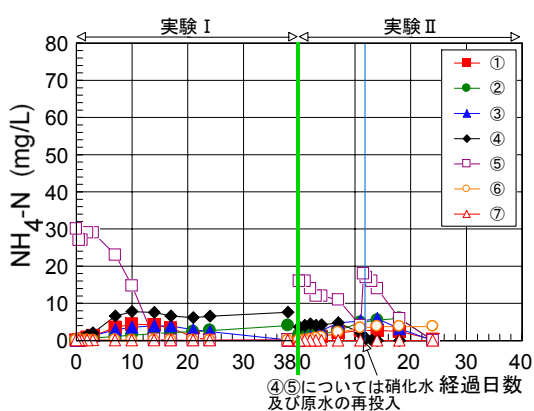

図-3アンモニア性窒素 $\mathrm{NH}_{4}-\mathrm{N}$ (実験I, II)

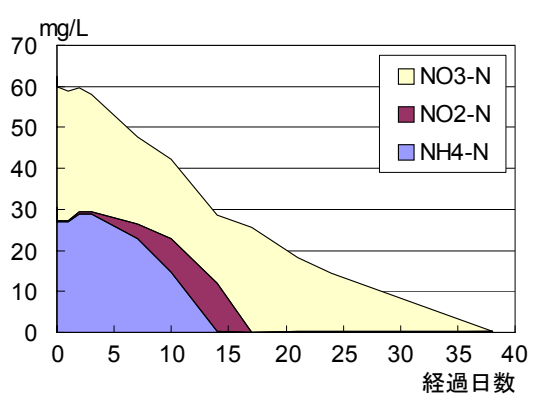

図-6 5)(実験|)における窒素成分の推移

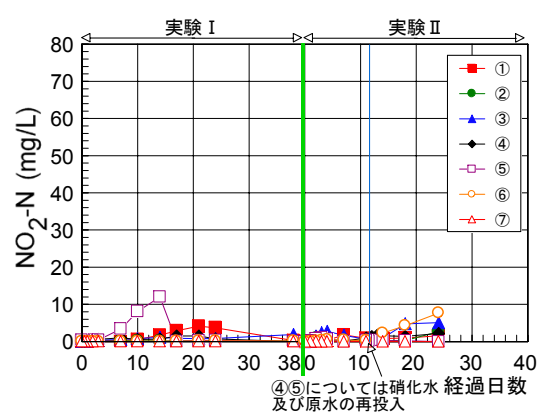

図-4 亜硝酸性窒素 $\mathrm{NO}_{2}-\mathrm{N}$ (実験I, II)

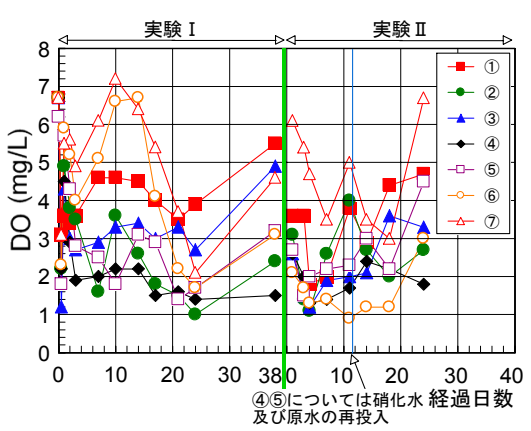

図-7 溶存酸素DO (実験I, II) 
平均的なORPやDOの濃度を大きく低下させるものでは ないが (図-7左側, 8左側)，還元的な液膜を担体や容器 壁面などへ局所的に形成させ，脱窒を促進する効果を発 揮すると推定される.

実験Iにおおる窒素成分の経時変化を図-2 5(右側)に 示す. (1)，(3)，(6)のケースでは試料水を新規に充填し て実験を開始したのに対し，(2)，(4)，(5)と参照ケースの (7)では実験Iの試料水を引き継いでいるため，すでに脱 窒菌が馴致され活性化している. そのため, 最初の10日 間においては，(2)，(4)，(5)における反応速度が(1)，(3)， (6)に比べて大きい.

(3) と(6)では同程度の速度で脱窒が進行し，(1)の反応は やや遅い. (1)と(3)の条件の違いは担体の有無だけである ので, 担体が脱窒菌の活性化にある程度機能しているこ とは確認される，一方，(3)では担体を投入し，(6)では担 体を投入せずに水素徐放剤を増量した．両者が同程度の 反応速度であったことから，担体・有機物増量の双方と も脱窒を促進しているようであるが，水素徐放剤が水面 に浮上する一方，担体は沈降していたため，両者が相乗 的に機能したわけではない，担体表面の脱窒菌が水素徐 放剤の有機物を効率よく取り込んで脱窒をさらに促進す るためには，実用上可能な水素徐放剤を担体に蒸着させ るなどの工夫が必要と考えられる.

(2)のケースでは，実験Iから引き継がれた脱窒菌の活 性度が高く, しかもメタノールから効率的に有機物が供 給されたため, 実験I開始後7日間におけるT-Nの減少速 度は全ケース中で最大であった.7日目以降から反応速 度が低下したが，これは，メタノールが消費されて有機 物が枯渇したことが原因と考えられる.このことは後述 のTOCの挙動（図-9右側）からも裏付けられる.

(4)と(5においても, 実験Iで添加された底泥により脱 窒菌数が多く存在し, 脱窒反応は活発である. そのため に，11日目には全窒素の大部分が除去され，反応が停止 した，そこで，試料水を 2 分の1に減らして，(4)につて は硝化水 $2.5 \mathrm{~L}$ ，5にについては硝化水 $1 \mathrm{~L}$ 原水 $1.5 \mathrm{~L} を そ$ れぞれ追加して実験を継続した。

\section{（2）溶存酸素濃度DOの経時変化（図-7）}

脱窒反忘はDO濃度やORPに依存する。一般には, DO が $0.5 \mathrm{mg} / \mathrm{L}$ 以下に至ると脱窒が生じると言われている.
しかし，全域的にDO濃度が高い場合においても，フ ロックなどに局所的な貧酸素水塊が形成されると脱窒が 進むことが知られている ${ }^{11)}$. これによると，図-7が示す ように，実験I，IIのいずれにおいても全てのケースにお いて無酸素状態には至っていないが, 脱窒反応がいくつ かのケースで確認された. 本実験では，フロックは形成 されていないが, 実験容器の壁面上や担体表面上で局所 的に脱窒が進んだものと考えられる.

\section{(3) 酸化還元電位ORPの経時変化（図-8）}

一般に, ORPが-50mV以下の場合に脱窒が進み，脱窒 の進行によってORPがさらに減少すると言われている ${ }^{11}$. 本実験の大半のケースではこのような脱窒に関するORP の必要条件が満たされていないが, DO と同様な状況で 脱窒は進行していると推定される. 実験 I は38日で終了 しており，実験 IIの最初の值が大きいのは外乱と考えら れる.

\section{（4）全有機炭素濃度TOCの経時変化（図-9）}

実験I，IIともに，メタノールを添加した(2)のケースで は，他のケースに比べて特徽的なTOCの挙動を示してい る. 窒素化合物の挙動（図-2 5）とも連動しているが, 実験I, II ともに, メタノールから供給された初期のTOC が脱窒反応に消費されて急速に減少している. 特に，実 験Iの期間中に馴致され担体投入によって脱窒菌が活性 化した実験IIの(2)のケースでは，TOCの消費速度が大き く，7日目前後にはすでに枯渴した. メタノールの消費 後の8日目以降，T-Nの減少は鈍化している.

\section{4. [還元剂, 脱窒菌環境, 有機物条件]が脱窒に およぼす効果}

表記の実駼結果に基づいて，表-2に示す各種投入物質 が脱窒におよぼす効果を検証する，窒素成分の濃度時系 列から表-4のような引き算によって各ケース間の濃度差 を算出し, [還元剤, 脱窒菌, 有機物］に関寸る影響因 子が窒素収支におよぼす効果を定量評価した．表-4左側 5つの引き算によって算出された還元剤と脱窒菌環境の 効果の結果を図-10 13に示寸．表-4右側5つの引き算に よって算出された有機物条件の効果の結果を図-14 17に

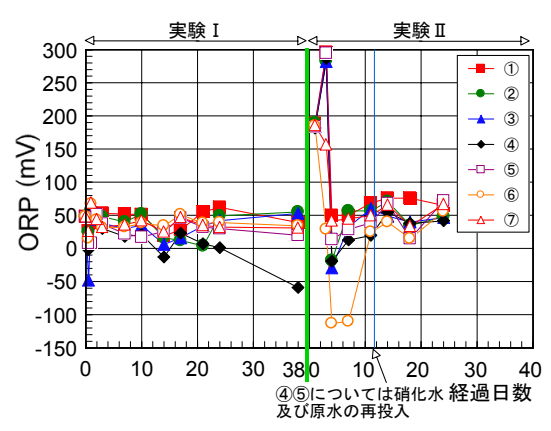

図-8 酸化還元電位ORP (実験I, II)

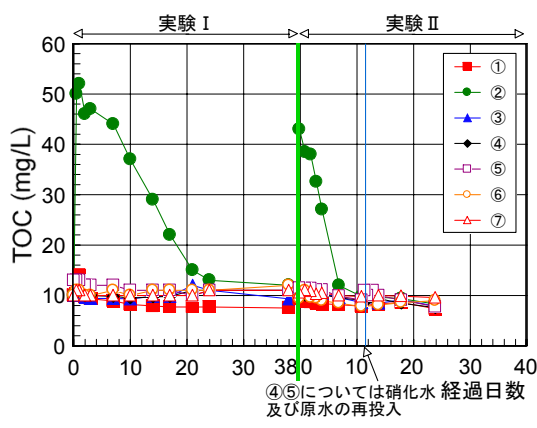

図-9 全有機炭素TOC (実験I, II)

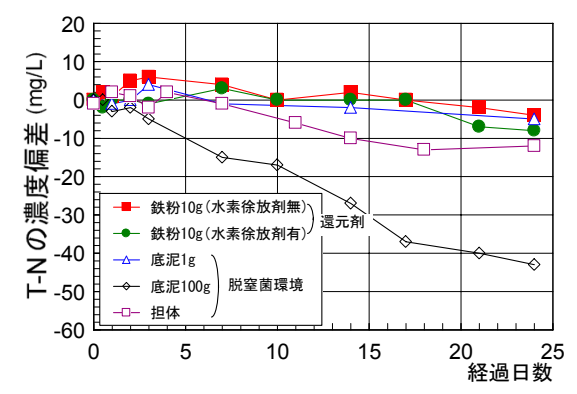

図-10 全窒素T-Nの濃度偏差 （還元剂と脱窒菌環境の効果） 
表-4＼cjkstart脱窒反応におよぼす投入物質の効果を検証するためのケース間の濃度偏差の算出

\begin{tabular}{|c|c|c|c|c|c|}
\hline \multirow{2}{*}{$\begin{array}{l}\text { 還元剂 } \\
\text { の効果 }\end{array}$} & 鉄粉10g（水素徐放剤無） & $\mathrm{I}(1)-\mathrm{I}(7)$ & \multirow{5}{*}{$\begin{array}{c}\text { 有機物条件 } \\
\text { の効果 }\end{array}$} & メタノール (鉄粉有) & I (2)- I (1) \\
\hline & 鉄粉10g（水素徐放剤有） & I (3)- I (6) & & 水素徐放剂10g（鉄粉無） & I (6)- I (7) \\
\hline \multirow{3}{*}{$\begin{array}{c}\text { 脱窒菌環境 } \\
\text { の効果 }\end{array}$} & 底泥1g（水素徐放剤・鉄粉有） & II (1) - I (3) & & 水素徐放剂10g（鉄粉有） & I (3)- I (1) \\
\hline & 底泥100g（水素徐放剂・鉄粉有） & I (4)- I (3) & & 水素徐放剤 $100 \mathrm{~g}$ (鉄粉・担体有) & II (6)- II (1) + I (3)- I (1) \\
\hline & 担体 (水素徐放剂・鉄粉有) & II (3)- II(1) & & 原水 & I (5)- I (1)-( I (4)- I (3) \\
\hline
\end{tabular}

(注) 各表三列目は左側から右側の実験ケースの濃度差を差し引くことを意味する.（Ｉ， II）は実験 I, II をそれぞれあらわし，丸番号は各ケースに 相当する.

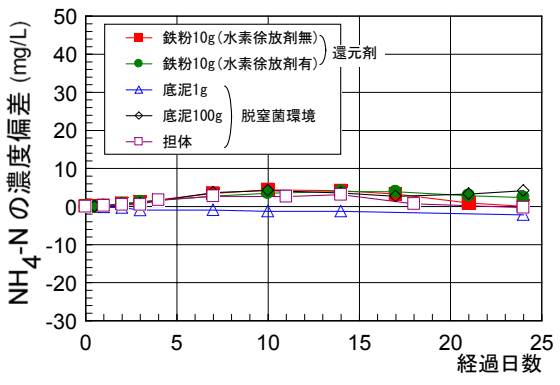

図-11アンモニア性窒素 $\mathrm{NH}_{4}-\mathrm{N}$ の濃度偏差 (還元剂と脱窒菌環境の効果)

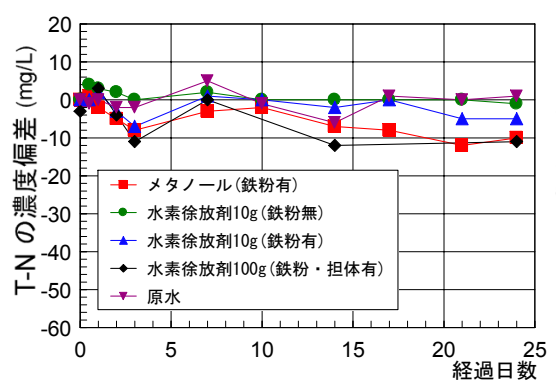

図-14 全窒素T-Nの濃度偏差 (有機物条件の効果)

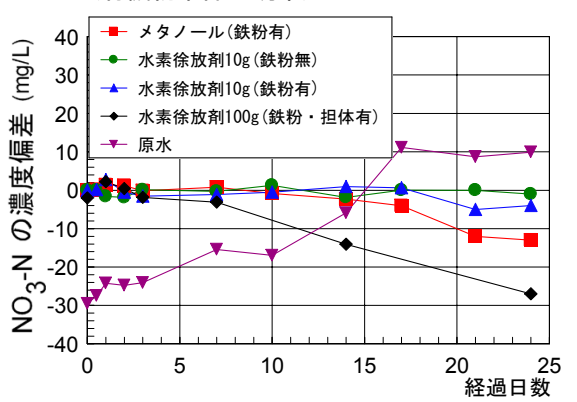

図-17 硝酸性窒素 $\mathrm{NO}_{3}-\mathrm{N}$ の濃度偏差（有機物条件の効果）

示す。なお，実験Iは38日間継続されたが，実験IIは(4)の ケースにおいて24日目に硝酸イオンが消費・枯渇して計 測を終了したため，全ケースに対し24日目までの濃度時 系列だけを対象とした。

\section{（1）還元剤および脱窒菌環境の効果}

図-10 13には還元剤ならびに脱窒菌を規定する環境諸 因子が窒素成分の挙動におよぼす影響を示す。図-10を 見るとT-Nの低減に対して鉄粉はわずかの効果を発揮し ている. 底泥の投入量も1g程度ではそれほど脱窒が進行 しているわけではない.

鉄粉だけを投入した場合と水素徐放剤を加えた場合を 比較するとその差はわずかであるので，水素徐放剤の還 元機能は認められるものの限定的である. 図-10と図-13

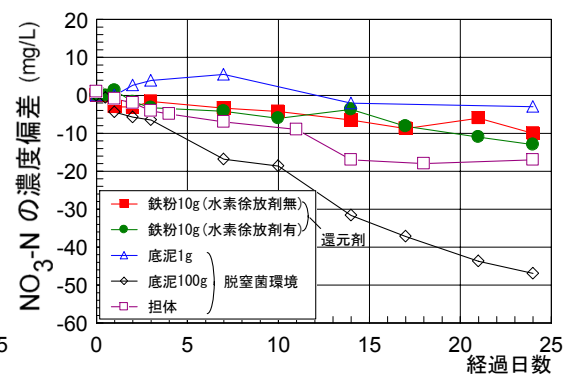

図-13 硝酸性窒素NO $3-\mathrm{N}$ の濃度偏差 (還元剂と脱窒菌環境の効果)

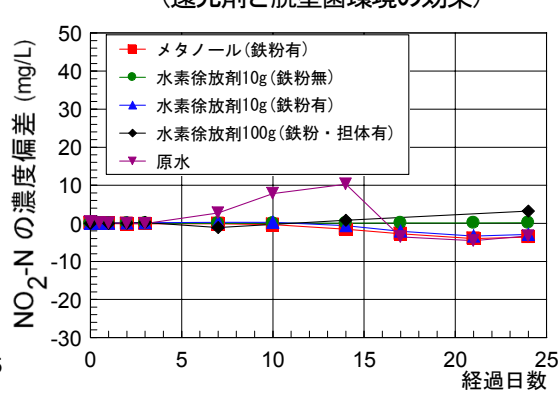

図-16 亜硝酸性窒素 $\mathrm{NO}_{2}-\mathrm{N}$ の濃度偏差 (有機物条件の効果) (有機物条件の効果)

に着目すると，いずれのケースもほぼ同様の濃度差時系 列を示している.このことから，除去された窒素の大部 分が $\mathrm{NO}_{3}$-Nであり, 脱窒は主に $\mathrm{NO}_{3}-\mathrm{N} \rightarrow \mathrm{N}_{2}$ の反応系で進 行していること，また，図-11，12に見られるように $\mathrm{NH}_{4}-\mathrm{N}$ と $\mathrm{NO}_{2}-\mathrm{N}$ の収支には，還元剤や脱窒菌環境の影響 が小さいことがわかる．ただし，鉄粉を添加したケース では，他のケースに比べて $\mathrm{NH}_{4}-\mathrm{N} の$ 微増が認められる. これには以下の還元反応が関与している可能性がある.

$4 \mathrm{Fe}(0)+\mathrm{NO}_{3}{ }^{-}+10 \mathrm{H}^{+} \rightarrow 4 \mathrm{Fe}^{2+}+\mathrm{NH}_{4}{ }^{+}+3 \mathrm{H}_{2} \mathrm{O}$

また, 底泥投入量が $1 \mathrm{~g}$ と $100 \mathrm{~g}$ の脱窒効果（T-Nの減 少）には大きな違いが見られる。したがって，ここで検 討した諸因子の中では脱窒菌の生息数が主たる律速条件 であることが確認される．担体の投入は $100 \mathrm{~g}$ 底泥投入 に次ぐ脱窒促進効果があるが，前述のように容器底の一 部を占める程度の担体投入量であったため，その効果は 限定的であったと考えられる.さらに多量に投入して微 生物付着面積を増加させる, 脱窒菌が有機物を有効に利 用できるように水素徐放剤を担体近辺に分布させるなど の工夫が必要である.

\section{（2） 有機物条件の効果}

本実験では，脱窒に必要な有機物源としてメタノール， 水素徐放剤，原水を添加し，それぞれの因子が脱窒にお 
よぼす影響を検証した。図-14 17に各因子がおよぼす影 響をケース間の濃度差時系列によって表示する。

図-14のT-N濃度偏差のうち水素徐放剤10gを添加した ケースを見ると，還元剤（鉄粉）を投入しない場合には T-Nがほとんど減少しておらず，水素徐放剤の効果がほ とんど発揮されてないことがわかる. その原因として, 鉄粉を投入した場合には鉄イオンが溶出する際に発生す る水酸化イオンが水素徐放剂の徐放を促進する ${ }^{10)}$ が，鉄 粉がない場合には水素徐放剂の徐放が促進されないこと が考えられる，そのため，今回使用した水素徐放剤 $10 \mathrm{~g}$ を単独に使用した場合には，溶解速度が小さすぎて脱窒 を促進する効果がほとんどないことがわかる.

一方，水素徐放剂を $100 \mathrm{~g}$ に増量添加した場合には， $\mathrm{NO}_{3}-\mathrm{N}$ 全てが $\mathrm{N}_{2}$ に還元されるのではなく，一部は $\mathrm{NH}_{4}$ $\mathrm{N} \mathrm{NO}_{2}$-N几還元されている（図-15 17）。したがって, $\mathrm{NO}_{3}$-NほどにはT-Nが減少していない。しかし，全体と してはメタノール添加の場合と同程度の脱窒効果を発揮 している(図-14）。

実機貯留池一の適用を考えた場合, メタノールは消費 速度が大きいため頻繁な添加が必要となり, 省力的な浄 化システムとしては適さない. 水素徐放剂の場合には, 水への溶解が緩慢であり耐用期間が長いので，より可能 性の高い脱窒工程と考えられる.

硝化水循環を想定した原水添加のケースにおいては, 添加直後の $\mathrm{NH}_{4}-\mathrm{N} の$ 増加, $\mathrm{NO}_{3}-\mathrm{N}$ の減少が見られ，その 後, 容器全体の好気的環境の影響で硝化が進むが（図15，17），全体として全窒素の増減は見られず，脱窒の 効果はほとんど認められなかった（図-14）。図-2の(5) のケースで脱窒が進行するのは, 底泥が有機物の供給源 になっているとも考えられる.

\section{5. おわりに}

経年化した廃䢂物埋立処分地からの浸出水の窒素負荷 を軽減することを目的として, 浸出水貯留池のマイクロ バブル曝気によって生成された硝化水を利用する脱窒処 理工程を実験的に検討した. 主な知見が以下のように要 約される.

1) 試料水が嫌気的ではなくとも，還元剤（鉄粉）など を添加することによって脱窒の進行を確認した。

2) 脱窒菌の供給源として貯留池の底泥は有効に脱窒促 進に対して機能することを確認した．また，本実験条 件内では担体の効果も限定的ではあるがみられた。 担 体近傍での脱窒菌の生息環境を適切に維持することに よって脱窒促進を期待することができる.

3) 水素徐放剂だけではなく鉄粉など水素徐放剤の機能 を最大化する措置を施すことにより，水素供与体の脱 窒促進効果を増加することが可能である.

4) 実用的で低廉な浄化システムとしての硝化水循環法 を想定し，メタノールに替わる有機物供給源として原
水を添加したが，脱窒反応は低調であった．下水処理 のように有機物を高濃度に含有する廃水処理の場合に は，硝化水循環が効率よく機能するが，経年化した廃 棄物埋立処分地からの浸出水の場合には脱窒反応を促 進するだけの十分な有機物を含んでいないと考えられ る. したがって, 浸出水の硝化液循環処理を実用化す る場合には，本実験での底泥添加のような工程によっ て有機物を人為的に供給する必要がある.

本浄化システムでは微生物濃度の維持が重要であり, 微生物濃度測定と浄化の状況の定量化を今後の課題とす る.

謝辞 : 実験と水質分析は, 神戸市環境保健研究所の伊藤 義明氏のご指導を得ながら実施された. また, 当時神戸 大学大学院の山田怜奈氏には実験とデータ解析にご協力 頂いた。記して謝意を表する.

\section{参考文献}

1) 道奥康治, 釬宮晃一, 山田怜奈, 伊藤義明, 八木正博, 中道 民広 : ゴミ埋め立て処分場からの浸出水のマイクロバブルに よる水質浄化，水工学論文集，第51巻，pp.1403-1408， 2007.

2) 道奥康治，山田怜奈，松本敏秀，釷宮晃一，中道民広，伊藤 義明, 八木正博, 原義晴 : 廃亲物堆積層からの浸出水の浄化 処理に関する実証試験, 水工学論文集, 第52巻, pp.12731278, 2008.

3) 松本敏秀, 道奥康治, 釷宮晃一, 山田怜奈 : 廃裹物埋め立て 処分場からの浸出水の脱窒処理技術の基礎的検討，第62回土 木学会年次学術講演会, 2007.

4) 本橋敬之助 : 水質浄化マニュアル技術と実例, pp.188-201, 海文堂, 2001.

5) 副島敬道, 伊藤雅子, 今村聡, 寺尾宏 : 透過性浄化壁工法に よる硝酸性窒素污染地下水の浄化技術, 大成建設技術研究所 報33，pp.71-74，大成建設技術研究所，2003.

6) 李盛源, 田瀬則雄 : 透水性浄化壁による硝酸性窒素の原位置 浄化，第11回地下水・土㙵污染とその防止対策に関寸る研究 集会要旨集, pp.41，2005.

7) 村澤浩一郎, 納村和美, 森崎久雄, 佐野明美, 寺田剛史, 田 井中善雄 : 高級脂肪酸を水素供与体として用いた水路の直接 脱空，水環境学会誌，Vol.25，No.12，pp.737-742， 2002.

8) 寺尾宏: 硝酸性空素による地下水污染とその浄化対策, 岐皁 県保健環境研究所報第14号, 2006.

9) 野原勝明, 坪田康信, 村井貞人, 高月修 : 水素徐放剂を用い た揮発性有機化合物污染土壤の浄化，地下水・土壇污染とそ の防止対策に関する研究集会講演集, 第9巻, pp.222-223, 2003.

10)環境省環境管理局水環境部 : 硝酸性窒素による地下水污染 対策事例集，pp.209-248，2004.

11)北尾高嶺: 生物学的排水処理工学, pp.242-246, コロナ社, 2003.

(2010. 9. 30受付) 